\title{
"Cyberbullying": A Disruptive Behaviour in Modern Day Secondary School Classrooms
}

\author{
Oyewusi, Lawunmi Molara
}

Department of Educational Technology, Obafemi Awolowo University, Ile-Ife, Osun State, Nigeria. oyewusilawunmi@yahoo.com

\section{Orolade, Kayode Stephen}

Department of Educational Technology, Obafemi Awolowo University, Ile-Ife, Osun State, Nigeria. kayodeorolade@gmail.com

\section{Doi:10.5901/jesr.2014.v4n6p421}

\section{Abstract}

\begin{abstract}
The prevalence of traditional bulling has drastically reduced in most Nigerian secondary schools due to various punishments meted out to the bullies. However, sequel to the technological affordances of secondary school students to own mobile phones as well as its ubiquitous ability has not only made internet connection efficient but also proffers another platform to better taunt peers in a more relaxed environment which is different from the usual face-to-face bullying. The purpose of the study is to position and familiarise the school with its supposed role as haven to those who are cybervictims and to enlighten the cyberbullies of the unintended consequences therein. The study involved 240 students who were randomly selected to participate in a questionnaire survey. The findings revealed that most students are not bothered with cyberbullying within the classroom environment but were disturbed outside the classroom environment. Although, students might be aware of the word "cyberbullying" but the consciousness have not been known to them like traditional or physical victimization and torture inflicted upon them by their peers
\end{abstract}

Keywords: Cyberbullying; traditional bullying; cyberspace; cybervictims; cyberbystander

\section{Introduction}

Traditional bullying usually occurs in schools during the period when students are less monitored or unsupervised (Fegenbush \& Oliver, 2009). The aftermath brings quarrelling and bruises which would later call the attention of school administrators. The prevalence of traditional bullying has drastically reduced among Nigerian secondary school students perhaps due to severe punishments that are usually meted out to the bullies by the teachers or the school administrators. Stephenson and Smith (1989) defined traditional bullying as "a form of social interaction in which a more dominant individual [the bully] exhibits aggressive behaviour which is intended to and does in fact, cause distress to a less dominant individual [the victim]. The aggressive behaviour may take the form of a direct physical and/or verbal attack or may be indirect when the bully hides a possession that belongs to the victim or spreads false information about the victim" (p. 45)

The act of cyberbullying usually occurs outside the school; however, its effect such as loss in concentration, truancy, loss of self esteem, anxiety and many others are brought into the classroom. This gives the teacher little or no idea of what is happening to the student(s) because it is different from the usual face-to-face tussles and quarrels on school ground. This is the age where students may no longer have solace even in their homes (Strom \& Strom, 2005) due to emotional distress, harassment, and disturbance inflicted upon them by their perpetrators who mostly commit such heinous acts at home in their own comfort zone (Dehue, Bolman, \& Llink, 2006). Furthermore, Parents of cybervictims may not easily comprehend the trauma of their children because it involves telecommunication technologies (Juvonen \& Gross, 2008) like Instant Messaging, social interaction through Social Media Networks and many others with which most African parents are unfamiliar with.

Shariff (2008) affirmed that the definition of cyberbullying should "illustrate the form it takes, the tools that are used to engage in it, and ways in which it is understood to differ from traditional bullying" (p. 29). Cyberbullying can therefore be described as the use of electronic methods of communication, such as the internet or a cell phone to repeatedly 
cause intentional harm or emotional distress (David-Ferdon \& Hertz, 2007; Patchin \& Hinduja 2006). Other electronic tools of cyberbullying include Instant Messaging (IM), Chat rooms, Social Network Sites, E-mail, Online fori and many others.

The activities on internet can be broadly categorized under three major themes - (i) commercial (ii) informational (iii) and communication (Kraut, Mukhopadhyay, Szczypula, Kiesler, \& Scherlis, 1998). Students generally tend towards informational (solving their assignments or social learning) and communication (online discussions or social interaction). Although, students might be aware of the word "cyberbullying" but the consciousness have not been known to them like traditional or physical victimization and torture inflicted upon them by their peers. Students perceive rumours as mere jokes and on such occasions they do not know they are cyberbullying others through their online behaviours such as (i) calling someone hurtful names, (ii) intentionally leaving person(s) out of things, (iii) teasing in a mean way, (iv) threaten or harass others, (v) spreading embarrassing photos or videos of others to the public and many more. These are made possible due to the prevalence of mobile phone with its ubiquitous capability to connect to internet which is affordable to many secondary school students in Nigeria.

The possession of mobile phone increases with age, grade or level of education (Cassidy, Jackson \& Brown, 2009). There is a thin line between traditional bullying and cyberbullying. Students generally spend the day with their friends in school and right after the closing of the school, they communicate online at night over what happened in the day (Patchin \& Hinduja, 2006). The cyberspace is just an extension of the bullying activities that might have occurred on the 'school space'. While traditional bullying might be physical and about one's popularity or fame, cyberbullying is more of internet proficiency (Patchin \& Hinduja, 2006) and ability to conceal one's identity (Ybarra \& Mitchell, 2004; Huang \& Chou, 2013).

Cyberbullying affects the physical, social, emotional and cognitive functioning and wellbeing of the victims. Patchin \& Hinduja (2006) gathered that $43 \%$ of victims of cyberbullying are frustrated, $40 \%$ felt angry, more than $27 \%$ felt sad, and $27 \%$ confessed that it affected them at home. cybervictims are also prone to psychosomatic symptoms like headaches, abdominal pains, and sleeplessness (Sourander et al., 2010). There is no limitation to potential perpetrators or victims of cyberbullying because of the array of sophisticated electronic communication devices that are readily available nowadays.

The question is: for how long will Nigeria secondary school students would be silent on the disruptive learning behaviour that emanates from cyberbullying? Will the parents and teachers continue to ignore or underestimate cyberbullying because it is free from physical injury or confrontation? Although little research has been done on cyberbullying with respect to Nigeria; the researchers therefore have chosen to investigate cyberbullying among secondary school students; examine its tools as well as how the school can wade in. In the course of this research, the researchers would:

(a) examine what cyberbully really mean to students;

(b) determine the extent to which students understand tools used in cyberbullying;

(c) distinguish cyberbullying from traditional bullying;

(d) examine how students cope or report cyberbullying;

(e) examine the effect(s) of cyberbullying on students' emotional or academic concentration;

(f) investigate how the school can wade in to reduce the prevalence of cyberbullying.

\section{Literature Review}

This section explores the meaning and gaps in cyberbullying, the adults and youngsters' opinion about cyberspace, as well as actors in cyberbullying.

\subsection{Meaning and gaps in cyberbullying}

A host of scholarly commentaries have affirmed that cyberbullying involves the use of electrical methods of communication such as the internet or a cell phone to repeatedly cause intentional harm or emotional distress (DavidFerdon \& Hertz, 2007; Patchin \& Hinduja 2006). In buttressing the description of cyberbullying, Shariff (2008) took account of the need to include the forms of cyberbullying and ways in which it is different from traditional bullying. In spite of this, there persists a gap in identifying the age bracket of the cyberbully or cybervictim. Aftab (2006) clarified that cyberbullying could only be perpetrated by child, preteen or teenager while adults could be involved in cyber-harassment or cyber stalking. Furthermore, Ybarra and Mitchell $(2004$, p.1311) reiterated the "repetitive nature" of cyberbullying 
conversely to Vandebosch and Cleemput (2009, p. 1351) who jettisoned the 'repitition criterion' of cyberbullying in the light of different types of electronic communication in which victims have options in deleting the e-mail, closing IM or shutting off the phone. "It is noteworthy to state that e-mails can be saved, IM and chat conversations can be logged and web pages can be archived for an offender, victim or third party to read over in future and thereby relive the experience" (Patchin \& Hiduja, 2006, p. 155).

\subsection{The adults and youngsters' opinion about cyberspace}

It is fascinating to know that youngsters' have different opinion to cyberspace contrary to the view of the adults. Some students believed that it is another realm of life where they could find (i) solace from the real world; (ii) take up different personality (iii) 'net-write' by using the shortest acronym possible (iv) socialise with old friends and meet new ones and many others. Alternatively, adults perceive cyberspace as another avenue that could be controlled as physical space (Cesaronic, et al., 2012). The attitude of youngsters to cyberspace makes cyberbullying ambiguous. The anonymity of the perpetrators of cyberbullying coupled with ubiquitous use of internet technologies by youngsters and the lack of interest or understanding of these technologies by many adults may mean what the adults are describing as cyberbullying is in fact a normal occurrence by the youngsters. For instance, pretending to be someone else or to take another identity is perceived to be a hurtful act of cyberbullying by the adults (Dehue, et al., 2006; Yabarra \& Mitchell, 2004; Cassidy, et al., 2009) but the youngsters sees it as funny and normal acts in cyberspace. Some youngsters even believe there is nothing that could be done to prevent or stop cyberbullying because the perpetrators are anonymous (Parris et al., 2012). Some youngsters sometimes consider the relationship between the sender and the receiver of the bullying act; that is, an online disagreement between friends may not necessarily be tagged cyberbullying. The adults believe that even if the cyberbullies are anonymous, they are traceable (Huang and Chou, 2013).

\subsection{Actors in cyberbullying}

The categorizations of the partakers in cyberbullying are as follows: (i) The cyberbully(s) (ii) The cybervictim(s), and (iii) The cyber-bystander(s). Unlike the traditional bullies that banks on their physical strength and stature (Patchin \& Hinduja, 2006), cyberbullies are more socially competent and have advance computer and internet use in concealing their identities (Vandebosch \& Cleemput, 2009; Huang \& Chou, 2013). Cyberbullies usually attack the victims they know offline and lack parental monitoring (Ybarra \& Mitchell, 2004; Vandebosch \& Cleemput, 2009). Aftab (2006) might have classified cyberbullies according to their intent of perpetration. He grouped them into: (a) The Vengeful Angels (b) The Revenge of the Nerds and (c) The Inadvertents.

The Vengeful Angels feel an individual or a group is victimizing their own person(s) and so, they want to get back to them online. The Vengeful angels' bullying act is usually known to a close friend or two. The Revenge of the Nerds mostly bullied traditionally. They are the most dangerous because their intention is best known to them. The Inadvertents do not understand their actions as cyberbullying. They do not mean to hurt but to be part of what is 'trendy'. They usually feel bad when they notice they are hurting or have denigrated someone.

Cassidy et al., (2009) itemized specific attributes which could make students victims of cyberbullying such as (i) special needs, (ii) academic abilities, (iii) un-popularity, (iv) physical appearance (v) physical and mental disabilities (vi) unfashionable clothing and ethnicity. Cybervictims are habitually harassed more than once by the same individual (Ybarra \& Mitchell, 2004). They depend more on internet and interacts with many unknown contacts online often which predisposes them to bully (Patchin \& Hinduja, 2006; Vandebosch \& Cleemput, 2009). The rapid dissemination of the acts of cyberbullying makes the cyber-bystander an important personality to consider. They are not just those who witness the bullying act as at the time it happened, but could also be after several days, or months (Shariff, 2008). They will always have an option of being part of the problem or the solution (Huang \& Chou, 2013).

\section{Research Methodology}

\subsection{Participants}

The quantitative survey consists of 240 senior secondary school students from both public and private schools in three major cities in South-West Nigeria. The study is restricted to senior secondary classes because of their possibility of possessing mobile phones. 


\subsection{Instrument}

The questionnaire consists of two sections. The section A solicits for demographic information of the students such as: sex, present class, type of school (private/public) as well as the age range. The section B consists of ten 4-level of 'never to very often' Likert scale; 5-multiple choice questions and 1 open ended question. However, the open ended has been coded into three themes.

\section{Findings and Discussion}

\subsection{Demographic background}

The study contains a cluster sampling of 240 students where $49.6 \%$ (119) are male and 504\% (121) are female. As shown in Table 1 below, the sample are stratified into types of school (private $=32.1 \%$, public $67.9 \%$ ) and class (SS1= $10.8 \%$, SS2 $=59.2 \%$, SS3=30\%).

Table 1. Demographic Analysis

\begin{tabular}{|c|c|c|}
\hline Description & Frequency & Percentage \\
\hline Gender & & 49.6 \\
Male & 119 & 50.4 \\
\hline Female & 121 & \\
\hline Class of respondents & 26 & 10.8 \\
\hline SS1 & 14.2 & 59.2 \\
\hline SS2 & 72 & 30.0 \\
\hline SS3 & & 32.1 \\
\hline School Type & 77 & 67.9 \\
\hline Private & 163 & \\
\hline Public & & \\
\hline
\end{tabular}

\subsection{Meaning of cyberbullying to Nigerian Secondary School Student}

Through observation, traditional bullying has drastically reduced in Nigerian secondary schools maybe due to severe punishment meted out to the bullies. From our findings, as indicated in table 1,67.5\% (52) of private school students never bullied physically while $58.9 \%$ (96) of students in public school do not physically bully. However, $2.8 \%$ of senior secondary school 3 (SS3) bully most. Upon examining online channels through which students cyberbully, 71.4\% (85) males do not bully via social network sites while $76 \%$ (92) of the female also do not cyberbully via social network site maybe because of their identity that could be revealed.

Table 1: Physical Bullying and Type of School.

\begin{tabular}{|l|c|c|c|c|c|}
\hline Description & Never & Sometimes & Often & Very often & Total \\
\hline Male respondent (\%) & 67.5 & 31.2 & 1.3 & 0.0 & 100 \\
\hline Female respondent (\%) & 58.9 & 35.0 & 4.3 & 1.8 & 100 \\
\hline Total (\%) & 61.7 & 33.8 & 3.3 & 1.2 & 100 \\
\hline
\end{tabular}

The ability to keep one's identity unknown is a unique method of asserting dominance which is quite impossible in traditional bulling. Table 2 depicts that $73.1 \%$ (87) of the males never disclose their identity when cyberbullying while $71.1 \%$ (86) of the female never disclose their identity when cyberbullying.

Table 2: Sex and Identity Disclosure during Cyberbullying

\begin{tabular}{|l|c|c|c|c|c|}
\hline Description & Never & Sometimes & Often & Very Often & Total \\
\hline Male respondent (\%) & 73.1 & 21.0 & 4.2 & 1.7 & 100 \\
\hline Female respondent (\%) & 71.1 & 19.0 & 6.6 & 3.3 & 100 \\
\hline Total (\%) & 72.1 & 20.0 & 5.4 & 2.5 & 100 \\
\hline
\end{tabular}


However, $63 \%(75)$ of male could identify the bully as well as $56.2 \%$ of the female could identify the bully. This supports the findings of Dehue, Bolman, and Llink (2006) that $34.5 \%$ of cybervictims could identify their bullies. Judging from the rate of online bullying via Instant Messaging (IM), table 3 depicts that $42.1 \%$ (50) of male cyberbully via IM and likewise, $33.8 \%$ (41) of female perpetrate such act. This confirms the findings of Vandebosch and Cleemput (2009) that boys find more ways of cyberbullying than the girls. The increased rate of cyberbullying via IM supports the findings of Ybarra \& Mitchell, (2004); Huang \& Chou, (2013); Patchin and Hinduja (2006, 2008); Dehue, Bolman, and Llink (2006). It noteworthy to state that the study found discovered that $71.4 \%$ (66) of male and $70.3 \%$ (64) of females are bystanders or witness to acts of cyberbullying.

It is important to state that many students still find teasing, insults or being called a foul language online despite being friend is an abuse. $61.3 \%$ (73) of male respondents affirmed this so also $57 \%$ (69) of female agreed to this.

Table 3: Sex and Cyberbullying via Instant Messaging

\begin{tabular}{|l|c|c|c|c|c|}
\hline Description & Never & Sometimes & Often & Very Often & Total \\
\hline Male respondent (\%) & 58.0 & 30.3 & 10.1 & 1.7 & 100 \\
\hline Female respondent (\%) & 66.1 & 23.1 & 6.6 & 4.1 & 100 \\
\hline Total (\%) & 62.1 & 26.7 & 8.3 & 2.9 & 100 \\
\hline
\end{tabular}

\subsection{Major tool used in cyberbullying}

The inseparability of the youngsters from their mobile phones is much of a concern. Although, the use of mobile phones is not allowed in most secondary school premises in Nigeria which were attested to according to in table $4.88 .3 \%$ (68) of private schools as well as $95.7 \%$ (156) do not allow students to use phones while in the school premise which might leads to distractions. Also, the affordability of mobile phone's camera to take and spread harmful pictures across the school in an instant which could enhance bullying (Froeschle, Mayorga, Castillo \& Hargrave, 2008). This study discovered that $48.7 \%$ (39) of the males share pictures, video, or audio files of peers without authorisation while $40.5 \%$ of the female do the same. This unauthorized sharing of media file bothers them alot.

Table 4: School Type and Permissibility of Phone

\begin{tabular}{|l|c|c|c|}
\hline Description & Yes & No & Total \\
\hline Private School (\%) & 11.7 & 88.3 & 100 \\
\hline Public School (\%) & 4.3 & 95.7 & 100 \\
\hline Total (\%) & 6.7 & 93.3 & 100 \\
\hline
\end{tabular}

Despite this, students still 'smuggle' their phones to school; as $54.5 \%$ of students in private schools secretly use their phones in school while $53.4 \%$ of students in public schools do the same. It is not a surprise to note that students connect to the internet through their phones. Table 5 depicts mobile phones as the most prevalent tool used in accessing the internet. It is noteworthy to state that $22.7 \%$ of public schools spend more than 5 hours online while $18.2 \%$ of private schools spend more than 5 hours online.

Table 5: Sex and Tools Used for Accessing the Internet

\begin{tabular}{|l|c|c|c|c|}
\hline Description & Mobile Phone & Laptop & Other devices & Total \\
\hline Male respondent (\%) & 89.9 & 6.7 & 3.4 & 100 \\
\hline Female respondent (\%) & 91.7 & 8.3 & 0.0 & 100 \\
\hline Total (\%) & 90.8 & 75 & 1.7 & 100 \\
\hline
\end{tabular}

\subsection{Effect of Cyberbullying within and Outside Classroom}

From the results of the study reveals that $68.9 \%$ (82) of male are not bothered so also $26.4 \%$ (11) of the female do not see cyberbullying as a reason not to concentrate on their studies in classroom. This goes along with the findings of Ybarra \& Mitchell, (2004) where 44\% of the students affirmed that cyberbullying does not affect their studies. However, table 6 describes how cyberbullying affect students at home where $39.5 \%$ of the males as well as $43.8 \%$ of the females 
are disturbed. This might be due to their present state of being connected to the internet as most of the students use their phone at home for internet connection (Cassidy, Jackson \& Brown, 2009).

Table 6: Sex and Extent of Cyberbullying Outside School

\begin{tabular}{|l|c|c|c|c|c|}
\hline Description & Never & Sometimes & Often & Very Often & Total \\
\hline Male respondent (\%) & 60.5 & 27.4 & 7.6 & 4.5 & 100 \\
\hline Female respondent (\%) & 56.2 & 34.7 & 7.4 & 1.7 & 100 \\
\hline Total (\%) & 58.3 & 32.1 & 75 & 2.1 & 100 \\
\hline
\end{tabular}

\subsection{Ways of Coping and Reporting Cases of Cyberbullying}

As indicated in table $8.46 .2 \%$ (55) of male prefers reporting cyberbullying cases to nobody while $47.9 \%$ (58) of female prefers reporting to friends.

Table 7: Sex and Reporting of Cyberbullying Cases

\begin{tabular}{|l|c|c|c|c|c|}
\hline Description & Parents & Teachers & Friends & Nobody & Total \\
\hline Male respondent (\%) & 10.9 & 5.9 & 37.0 & 46.2 & 100 \\
\hline Female respondent (\%) & 10.7 & 50 & 47.9 & 36.4 & 100 \\
\hline Total (\%) & $10.8 \%$ & $5.4 \%$ & $42.5 \%$ & $41.2 \%$ & 100 \\
\hline
\end{tabular}

Students would cope with issues of cyberbullying as indicated in table 10, most students would logout but $30.3 \%$ of male would bully back while $38.8 \%$ of the female would prefer deleting the message or pictures.

Table 8: Sex and Coping with Cyberbullying

\begin{tabular}{|l|c|c|c|c|}
\hline Description & Parents & Teachers & Friends & Total \\
\hline Male respondent (\%) & 23.5 & 46.2 & 30.3 & 100 \\
\hline Female respondent (\%) & 38.8 & 48.8 & 12.4 & 100 \\
\hline Total (\%) & 31.2 & 47.5 & 21.2 & 100 \\
\hline
\end{tabular}

\subsection{School's Intervention to Cyberbullying}

According to table 9 , both male and female $47.1 \%$ and $60.2 \%$ respectively expressed that the school can wade into cases of cyberbullying by enlightenment on internet etiquette. This supports the findings of Froeschle, Mayorga, Castillo \& Hargrave (2008) who affirmed that educators could create awareness by enlightening all students of what cyberbullying is and the importance of not supporting such act. There are relatively few student who wanted the school to organise PTA meeting because of retribution and fear taking their phones from them.

Table 9: Sex and School's Intervention to Cyberbullying

\begin{tabular}{|l|c|c|c|c|}
\hline Description & $\begin{array}{c}\text { Interaction with } \\
\text { Teachers }\end{array}$ & $\begin{array}{c}\text { Enlightenment on } \\
\text { internet etiquette }\end{array}$ & $\begin{array}{c}\text { Parents' Teachers' } \\
\text { Association meeting }\end{array}$ & Total \\
\hline Male respondent (\%) & 34.5 & 47.1 & 18.5 & 100 \\
\hline Female respondent (\%) & 25.6 & 62.0 & 12.4 & 100 \\
\hline Total (\%) & 30 & 54.6 & 15.4 & 100 \\
\hline
\end{tabular}

\section{Concluding Remarks}

Although the school prohibits the use of phones in the school premises, the integration of mobile phones into teaching and learning would be a promising endeavour for the school administrator to engage the students. In addition, the school should also enhance their guidance and counselling section as well as orientating the students the duties and functions of the section. The parents should also be encouraged to do a routine check on their children's phone. This will give them 
the idea of what they might be doing online.

Cyberbullying is an 'emerging norm' that very few perceive as evil and most people do not realise the consequence of the unintended result. The school would be a better place to reduce it to the minimum.

\section{References}

Aftab, P. (2006). Stop Cyberbullying. WiredKids, Inc. Retrieved Nov., 28, 20013 from http://www.stopcyberbullying.org/doc/ what_is_cyberbullying_exactly.doc

Cassidy, W., Jackson,M. \& Brown, K.N (2009). Sticks and Stones Can Break my Bones, But How Can Pixels Hurt Me?: Students' Experiences with Cyber-Bullying. School Psychology International. 30: 383 DOI: 10.1177/0143034309106948

Cesaroni, C; Downing, S; \& Alvi, S (2012). Bullying Enters the 21st Century? Turning a Critical Eye to Cyberbullying Research. Youth Justice, 12(3) $199-211$

David-Ferdon, C. and M.F. Hertz (2007) 'Electronic Media, Violence, and Adolescents: An Emerging Public Health Problem', Journal of Adolescent Health 41(6): S1-5.

Dehue, F; Bolman, C; Llink T.V. (2006). Cyberbullying: Youngster' Experiences and Parental Perception. (unpublished)

Fegenbush and Oliver (2009).Paper presented at the Annual Meeting of the Louisiana Education Research Association, Lafayette.

Froeschle, Mayorga, Castillo \& Hargrave (2008). Strategies to Prevent and Heal the Mental Anguish Caused by Cyberbulling. Middle School Journal Vol. 39(4) 30-35

Juvonen, J., \& Gross, E. F. (2008). Extending the school grounds? Bullying experiences in cyberspace. Journal of School Health, 78, 496-505.

Kraut, R. E., Patterson, M., Lundmark, V., Kiesler, S., Mukopadhyay, T., \& Scherlis, W. (1998). Internet paradox: A social technology that reduces social involvement and psychological well-being?American Psychologist,53, 1017-1031.

Patchin, J.W., \& Hinduja , S. (2006) Bullies Move Beyound the Schoolyard: A preliminary Look at Cyberbullying. Youth Violence and Juvenile Justice, Vol. 4, No. 2, 146-169. DOI: 10.1177/1541204006286288

Ybarra, M.L., \& Mitchell, J.K., (2004).Online aggressor/targets, aggressors and targets: A comparison of associated youth characteristics. Journal of Child Psychology and Psychiatry, 45, 1308-1316

Shariff S (2008) Cyber-bullying: Issues and Solutions for the School, the Classroom and Home. New York: Routledge.

Sourander, A., Brunstein Klomek, A., Ikonen, M., Lindroos, J., Luntamo, T., Koskelainen, M., et al. (2010). Psychological risk factors associated with cyberbullying among adolescents. A population-based study.Archives of General Psychiatry, 67,720-828.

Parris, Varjas, Meyers and Cutts (2012). High School Students' Perception of coping with Cyberbullying. Youth \& society 44 (284). DOI: $10.1177 / 0044118 \times 11398881$

Stephenson, P., \& Smith, D. (1989). Bullying in junior school. In D. P. Tattum \& D. A. Lane (Ed.),Bullying in schools(pp. 45-58). Strokeon-Trent, UK: Trentham

Strom, P. S., \& Strom, R. D. (2005). When teens turn into cyberbullies. Educational Forum, 70, 21-36.

Huang, Y., \& Chou, C. (2013). Revisiting cyberbullying : Perspectie from Taiwanese teachers. Computers \& Education, 63, 227-239. http://dx.doi.org/10.1016/j.compedu.2012.11.023

Hinduja, S. \& Patchin, J.W (2008). Cyberbullying : an exploratory analysis of factors related to offending and victimization. Deviant Behaviour, 29: 129-156. DOI: 10.1080/01639620701457816

Vandebosch, H. \& Cleemput, V.K (2009). Cyberbullying among youngsters: profiles of bullies and victims. New Media \& Society, Vol. 11(8) 1349-1371, [DOI: 10.1177/1461444809341263] 
ISSN 2239-978X

ISSN 2240-0524
Journal of Educational and Social Research MCSER Publishing, Rome-Italy
Vol. 4 No. 6 September 2014 